\title{
Influencing Factors Identification of Green Growth in China Based on Entropy-DEMATEL Model
}

\author{
Ling-ling Guo, Chun-you Wu, Jing-tao Yu \\ Faculty of Management and Economics, Dalian University of Technology, Dalian, China
}

\begin{abstract}
With the green economy era coming, the problem of regional green growth has received wide attention of the international community. It becomes a hot issue to identify the key influencing factors of green growth objectively and scientifically. The indicators in this paper have been selected from social economy, resources and environment, natural assets and policy support. Using correlation analysis screen the indicators quantitatively, and the indicators are deleted under the same criterion layer when their correlation coefficients are greater than 0.9. According to the disadvantages of traditional DEMATEL (Decision-Making Trial and Evaluation Laboratory), the entropy-DEMATEL model is proposed to analyze the preserved 15 indicators, getting the cause factors, the effect factors and the influencing degree of each index. The results show that energy is not only the largest influencing factor, but also the cause factor, and it will become the basic motive force to promote the green development of China's economy.
\end{abstract}

Keywords-green growth; influencing factors; entropy method; DEMATEL method

\section{INTRODUCTION}

Increasing conflicts between natural resources depletion and economic growth have posed enormous threaten on the benign relations between nature and human. How to keep economic growth in a green way and to enhance greening capability therefore has become a significant focus. In 2012, a basic state policy of "striving for green, circular and low-carbon development" was promoted in the report during the opening ceremony of the 18th CPC National Congress. According to the World Bank, China has been the second energy consumer and biggest $\mathrm{CO}_{2}$ emitter globally as China contributed 20.85\% of global $\mathrm{CO}_{2}$ emissions in 2009 [1]. Transiting to a green growth pattern is an imperative pathway for China to achieve sustainable development.

Green growth relates to various aspects including economy, resource, environment, technique, policy, market, culture, population, and so on. The existing studies have been done regarding technological innovation, resources conservation, supporting policies and financial markets.

In terms of technological innovation, green technology is identified as fundamental support to realize green and sustainable development [2], and supported by lots of research [3, 4]. In terms of resources and environment, OECD has indicated that economic growth potential will be hindered when the costs of resource exploitation exceed the benefits of economic gains [5]. Zhu considers resource productivity and eco-performance are the two main determinants of city green competitiveness [6]. John points out that there should be a comprehensive thinking of resource depletion, environmental degradation, and the efforts to mitigate constrains of resources and environment [7]. In the light of policy making, combination and design of policy tools have been core topics for green growth [8]. UNESCAP indicates that a green growth policy framework should incorporate green taxes, sustainable production and consumption, green markets and so on [9]. Governments have taken green growth policies into the major policy frameworks to balance divergent policy goals to harmony economy, environment and society [10]. Designing a green policy framework needs to pay attention to multilevel governance [11], policy failure adjustment [12] and systematic policy evaluation [13]. In terms of financial market, Liu discovers that the maturity of the domestic financial market is positively related to the continuous economic development [14]. Zhang suggests that stable political situation, open trade environment and adequate investment have positive effects on Chile's green growth [15].

Although previous studies have provided extensive theories and methods for green growth, an in-depth study is needed to expand the understanding for the topic: (1) the existing selected indicators and evaluation frameworks are more subjective than objective, which compromises the scientific of the evaluation; (2) systematic studies regarding the interaction between factors and corresponding solutions are still missed in the existing literature.

This study is conducted as below: First, indicators are selected from social economy, resources and environment, natural assets and policy support. Second, the entropy method is employed to set up a matrix for the indicators' weights, followed by a DEMATEL method to determine key influencing factors of the green growth. Last but not least, pragmatic implications for assisting China's green growth are provided based on the obtained results.

\section{PRELIMINARY KNOWLEDGE}

\section{A. Introduction of traditional DEMATEL}

DEMATEL method (Decision-Making Trial and Evaluation Laboratory) proposed by the Science and Human Affairs Program of the Battelle Memorial Institute of Geneva between 1972 and 1976, was used for solving the complicated and intertwined problems [16]. In recent years, DEMATEL method has been widely applied in theory innovation, practice applications and model development, which has laid a good foundation for this study.

The procedure of DEMATEL method is described as follows: 
Definition 1: Define the direct-relation matrix $A=\left(a_{i j}\right)_{n \times n}$, where $a_{i j}$ stands for the relative important of index $i$ to index $j, i, j=1,2, \cdots, n$.

Definition 2: Define the normalized matrix

$$
B=s \cdot A \text {, where } s=\frac{1}{\max _{1 \leq i \leq n} \sum_{j=1}^{n} a_{i j}} \text {. }
$$

Definition 3: Define the total relation matrix $T$. Define $T=B(I-B)^{-1}$, where $I$ stands for the unit matrix.

Definition 4: Define the "Prominence" and "Relation" of the index. Let $t_{i j}(i, j=1,2, \cdots, n)$ be the elements of $T$; then, the sum of the rows and the columns are denoted as $D$ and $R$, respectively, and the formulas are:

$$
\begin{aligned}
& D=\left(t_{i}\right)_{n \times 1}=\left(\sum_{j=1}^{n} t_{i j}\right)_{n \times 1} \\
& R=\left(t_{\cdot j}\right)_{1 \times n}=\left(\sum_{j=1}^{n} t_{i j}\right)_{1 \times n}
\end{aligned}
$$

Define $D_{i}+R_{i}$ as the "Prominence" of index $i$, which shows how important the index is. The bigger the value of $P_{i}$ is, the more important index $i$ is. Define $D_{i}-R_{i}$ as the "Relation" of index $i$. If the value is positive, the index belongs to the cause group. If the value is negative, the index belongs to the effect group. Through the "Prominence" and "Relation," we can clearly define the complicated causal relationships between factors in the system, so as to reveal the internal structure of the system.

\section{B. Entropy method}

Entropy method is a common objective weighting method. It is generally believed that the high the information entropy value is, the more balanced the system structure is, vice versa [17]. According to the variation degree of each index, we can calculate the weight of each index. Its steps are:

(1) Normalizing the data: where $x_{i j}$ stands for the value of index $j$ in year $i(i=1,2, \cdots, m ; j=1,2, \cdots, n)$.

If the index is a benefit-type index, there is:

$$
x_{i j}^{\prime}=\frac{x_{i j}-x_{\min (j)}}{x_{\max (j)}-x_{\min (j)}}
$$

If the index is a cost-type index, there is:

$$
x_{i j}^{\prime}=\frac{x_{\max (j)}-x_{i j}}{x_{\max (j)}-x_{\min (j)}}
$$

(2) Determining the proportion:

$$
Y_{i j}=\frac{x_{i j}^{\prime}}{\sum_{i=1}^{n} x_{i j}^{\prime}}
$$

(3) Calculating the entropy value:

$$
e_{j}=-\frac{1}{\ln n} \sum_{i=1}^{n} Y_{i j} \ln Y_{i j}
$$

(4) Calculating the weight:

$$
w_{j}=\frac{1-e_{j}}{\sum_{j=1}^{m}\left(1-e_{j}\right)}
$$

\section{ENTROPY-DEMATEL MODEL}

The key of DEMATEL method is to establish the direct-relation matrix. Because of the data of traditional DEMATEL method comes mainly from expert grading or questionnaire, and there are the following defects: firstly, the subjectivity is strong, and will affect the accuracy of the evaluation results; secondly, due to the differences of each expert, the analysis results tend to be unstable. To make up for the deficiencies, this paper tries to use the entropy method to establish the direct-relation matrix between indicators. The detailed steps are as follows:

(1) Weight the index through the entropy method $w_{i}(i=1,2, \cdots, n)$.

(2) Establish the direct-relation matrix by the entropy value.

$A=\left(a_{i j}\right)_{n \times n}=\left[\begin{array}{cccc}a_{11} & a_{12} & \cdots & a_{1 n} \\ a_{21} & a_{22} & \cdots & a_{2 n} \\ \vdots & \vdots & \vdots & \vdots \\ a_{n 1} & a_{n 2} & \cdots & a_{n n}\end{array}\right]=\left[\begin{array}{cccc}0 & w_{1} / w_{2} & \cdots & w_{1} / w_{n} \\ w_{2} / w_{1} & 0 & \cdots & w_{2} / w_{n} \\ \vdots & \vdots & 0 & \vdots \\ w_{n} / w_{1} & w_{n} / w_{2} & \cdots & 0\end{array}\right]$

$$
\text { where } a_{i i}=0, a_{i j}=w_{i} / w_{j} \text {. }
$$

(3) Normalize the direct-relation matrix by the entropy value (see Definition 2).

(4) Calculate the total relation matrix (see Definition 3).

(5) Construct the cause and effect diagram (see Definition 4). 
TABLE I. THE INDEX SYSTEM OF GREEN GROWTH.

\begin{tabular}{|c|c|c|}
\hline $\begin{array}{l}\text { Criterion } \\
\text { layer }\end{array}$ & Index layer & $\begin{array}{l}\text { Screening } \\
\text { results }\end{array}$ \\
\hline \multirow{6}{*}{$\begin{array}{l}\text { Social } \\
\text { economy }\end{array}$} & $\begin{array}{l}\text { Green gross domestic product (GDP) per } \\
\text { capita }\end{array}$ & \multirow{3}{*}{ Keeping } \\
\hline & Natural growth rate of population & \\
\hline & Market openness & \\
\hline & Proportion of tertiary industries & \multirow{3}{*}{ Deleting } \\
\hline & $\begin{array}{l}\text { Per capita annual disposable income of } \\
\text { urban households }\end{array}$ & \\
\hline & Labor productivity of the whole society & \\
\hline \multirow{10}{*}{$\begin{array}{l}\text { Resources } \\
\text { and } \\
\text { environment }\end{array}$} & Primary energy consumption & \multirow{5}{*}{ Keeping } \\
\hline & $\begin{array}{l}\text { Proportion of renewable energy } \\
\text { consumption }\end{array}$ & \\
\hline & $\begin{array}{l}\text { Total volume of industrial waste water } \\
\text { discharged }\end{array}$ & \\
\hline & $\begin{array}{l}\text { Cumulative land area by mines } \\
\text { occupancy destroyed }\end{array}$ & \\
\hline & $\begin{array}{l}\text { Economic losses of environmental } \\
\text { emergencies }\end{array}$ & \\
\hline & $\begin{array}{l}\text { Water consumption per industrial value- } \\
\text { added }\end{array}$ & \multirow{5}{*}{ Deleting } \\
\hline & $\begin{array}{l}\text { Households electricity consumption per } \\
\text { capita }\end{array}$ & \\
\hline & Carbon dioxide $\left(\mathrm{CO}_{2}\right)$ emissions & \\
\hline & $\begin{array}{l}\text { Total volume of industrial waste gas } \\
\text { emissions }\end{array}$ & \\
\hline & $\begin{array}{l}\text { Volume of industrial solid wastes } \\
\text { produced }\end{array}$ & \\
\hline \multirow{4}{*}{$\begin{array}{l}\text { Natural } \\
\text { assets }\end{array}$} & Water resources per capita & \multirow{4}{*}{ Keeping } \\
\hline & Forest coverage rate & \\
\hline & Ensured reserves of coal & \\
\hline & Nature reserves coverage rate & \\
\hline \multirow{6}{*}{$\begin{array}{l}\text { Policy } \\
\text { support }\end{array}$} & Proportion of expenditures on R\&D & \multirow{3}{*}{ Keeping } \\
\hline & $\begin{array}{l}\text { Proportion of environmental pollution } \\
\text { treatment investment }\end{array}$ & \\
\hline & $\begin{array}{l}\text { Comprehensive utilization rate of } \\
\text { industrial solid wastes }\end{array}$ & \\
\hline & Full-time equivalent of R\&D personnel & \multirow{3}{*}{ Deleting } \\
\hline & $\begin{array}{l}\text { Expenditures of science, education, } \\
\text { culture and health }\end{array}$ & \\
\hline & $\begin{array}{l}\text { Standard-reaching rate of industrial waste } \\
\text { water discharged }\end{array}$ & \\
\hline
\end{tabular}

The advantages of Entropy-DEMATEL model are that can increase the credibility of the results, significantly reduce the calculation amount and process, which can expand the application range of traditional DEMATEL method.

\section{MODEL APPLICATION}

\section{A. The index system}

The index system of green growth is consisted by a series of interacted indicators, and can reflect the actual situation of green growth. Referring to the relevant index systems $[18,19]$ and considering the existing condition of China's green development, the indicators have been selected from social economy, resources and environment, natural assets and policy support (Table I).

The paper uses the Min-Max method to standardize the original data. Natural growth rate of population is the moderate index. According to the planning objective of national population growth rate during the period of " 12 th five-year," the paper determines $7.2 \%$ as the ideal value of the index [20].

To avoid the redundant indicators' impact, the paper applies correlation analysis to screen the influencing factors and deletes the indicators under the same criterion layer when their correlation coefficients are greater than 0.9 . It can reduce the duplicate information the indictors reflected. Correlation analysis is implemented by SPSS 18.0, and the results are shown in Table 1's third column.

\section{B. The calculation results}

Based on the Entropy - DEMATEL model, the paper exploits Matlab 7.9.0 programming to calculate the values of $D+R$ and $D-R$ (Table 2).

TABle II. The Prominence AND Relation OF THE INDICATORS

\begin{tabular}{|l|r|r|}
\hline \multicolumn{1}{|c|}{ Indicators } & $D+R$ & $D-R$ \\
\hline 1.Green GDP per capita (yuan) & 1.1211 & -0.2427 \\
\hline 2.Natural growth rate of population (\%) & 1.1020 & -0.1199 \\
\hline 3.Market openness (\%) & 1.1226 & -0.2498 \\
\hline 4.Primary energy consumption (10 ${ }^{4}$ tce) & 1.2973 & 0.7079 \\
\hline $\begin{array}{l}\text { 5.Proportion of renewable energy } \\
\text { consumption (\%) }\end{array}$ & 1.6687 & 1.2795 \\
\hline $\begin{array}{l}\text { 6.Total volume of industrial waste water } \\
\text { discharged (10 } \text { tons) }\end{array}$ & 1.0961 & -0.0292 \\
\hline $\begin{array}{l}\text { 7.Cumulative land area by mines occupancy } \\
\text { destroyed (hectares) }\end{array}$ & 1.1165 & -0.2192 \\
\hline $\begin{array}{l}\text { 8.Economic losses of environmental } \\
\text { emergencies (10 } \text { yuan) }\end{array}$ & 1.0992 & -0.0905 \\
\hline 9.Water resources per capita (m ${ }^{3}$ ) & 1.2202 & 0.5474 \\
\hline 10.Forest coverage rate (\%) & 1.1270 & -0.2693 \\
\hline 11.Ensured reserves of coal (10 ${ }^{8}$ tons) & 1.0974 & 0.0621 \\
\hline 12.Nature reserves coverage rate (\%) & 1.3567 & -0.6892 \\
\hline 13.Proportion of expenditures on R\&D (\%) & 1.1745 & -0.4320 \\
\hline $\begin{array}{l}\text { 14.Proportion of environmental pollution } \\
\text { treatment investment (\%) }\end{array}$ & 1.2844 & 0.6830 \\
\hline $\begin{array}{l}\text { 15.Comprehensive utilization rate of } \\
\text { industrial solid wastes (\%) }\end{array}$ & -0.9380 \\
\hline
\end{tabular}

\section{Results analysis}

According to the value of $D+R$, proportion of renewable energy consumption has the greatest impact on China's green growth. The second is comprehensive utilization rate of industrial solid wastes. Greater the value of the "Prominence" is, more obvious the effect of the index becomes. To realize green development, energies and pollutants are still the most important factors. Therefore, optimizing energy consumption structure and improving waste recycling capacity are the most important measures to address the practice of green growth in China.

Depending on the value of $D-R$, the cause factors are proportion of renewable energy consumption, primary energy consumption, proportion of environmental pollution treatment investment, water resources per capita and ensured reserves of coal. The remaining 10 indicators are the effect factors. Five cause factors are the basic 
driving force of the green growth. While these 10 effect factors are the most direct powers to promote green growth, and are the important media which the cause factors impact on green growth. Therefore, to achieve China's green growth, we need to begin with the five cause factors. Energy is both a greatest impact factor and the cause factor, and it is the fundamental element to promote green growth in our country.

\section{CONCLUSIONS}

This paper uses the entropy weight to build the directrelation matrix and gets a good result. The entropy DEMATEL method overcomes the limitation of traditional DEMATEL, and expands the application range of the method. According to the research results, proportion of renewable energy consumption is not only the greatest influencing factor, but also the cause factor. Therefore, green growth in China needs to take measures from energy aspect.

The specific measures are as follows: (1) optimizing energy consumption structure. For a long time, China's energy consumption structure has dominated by coal, oil and natural gas, because of their non-renewable nature, and the sustainability of energy consumption would be threatened. The top priority is to accelerate the application of renewable energy resources and realize the diversified consumption structure; (2)strengthening energy strategic reserve. Since the reform and opening up, China has rapid economic development. But the extensive growth mode makes the severe depletion of primary energy in China. The phenomena that are the shortages of oil, coal, gas and electricity occur frequently, which seriously endanger the stability of energy security. Therefore, strengthening energy strategic reserve is urgent; (3)reinforcing energysaving technologies application. Promoting energy-saving technologies in energy-intensive industries is the focus, and strengthening the international advanced energysaving technologies introduction is needed. Compared with developed countries, there are still large gaps of energy-saving technologies. Reinforcing technology import is the best way to bridge this gap within a short time.

Please note that this paper only analyzes the influencing factors of green growth, without involving the mechanism, operation mode and other important issues. Consequently, the above topics can be deeply discussed in future studies.

\section{ACKNOWLEDGMENTS}

This research is funded by the National Nature Science Foundation of China (No. 71320107006; No. 71103024; No. 71473029).

Corresponding author: Ling-ling Guo, Tel.: +86 15040548596; fax: +86 411 84707955. E-mail address: guolingling_517@163.com (L. Guo).

\section{REFERENCES}

[1] World Bank, World Development Indicators[M]. World Bank, Washington, 2009.

[2] D.E. James, H.M.A. Jansen, J.B. Opschoor, Economic Approaches to Environmental Problem [M]. Elsevier Scientific Publishing Company, Amsterdam, 1978.

[3] Li Ping, Study on the subject system of green technology innovation [D]. Studies in Science of Science, 23(3), pp. 414-418, 2005.

[4] Frances Cairneross, Economic Tools, International Trade and the Role of Business Sustainable Development: the Challenge of Transition [M]. Cambridge University Press, pp. 153-174, 2000.

[5] OECD, Towards green growth [R]. OECD Meeting of the Council, 2011.

[6] Zhu Dajian, Studies on China urban green transition based on PSR analysis [J]. Tongji University Journal Social Science Section, (4), pp. 37-47, 2011.

[7] J.M. Reilly, Green growth and the efficient use of natural resources [J].Energy Economics, (34), pp. 85-93, 2012.

[8] OECD, Interim Report of the Green Growth Strategy: Implementing our Commitment for a Sustainable Future [R]. Meeting of the OECD Council at Ministerial Level, 2010.

[9] UNESCAP, Green Growth Capacity Development Programme [R], 2009.

[10] OECD, Green Growth and Transport [R]. International Transport Forum, 2011.

[11] M.A. Schreurs, Breaking the impasse in the international climate negotiations: the potential of green technologies [J]. Energy Policy, (48), pp. 5-12, 2012.

[12] Min Jung Kang, Heejun Park, Impact of experience on government policy toward acceptance of hydrogen fuel cell vehicles in Korea [J].Energy Policy, (39), pp. 3465-3475, 2011.

[13] C. Knill, S. Heichel, D. Arndt, Really a front-runner, really a straggler? of environmental leaders and laggards in the European Union and beyond -- A quantitative policy perspective [J]. Energy Policy, (48), pp. 36-45, 2012.

[14] Liu Hongzhong, Yang Gongyan, The rise of emerging economies and changes in world economy [J].Economist, (1), pp. 81-88, 2012.

[15] Zhang Yong, Innovation, growth and equality: Chile's national competitiveness [J]. Journal of Latin American Studies, 30(5), pp. 23-30, 2008.

[16] G.H. Tzeng, C.H. Chiang, C.W. Li, Evaluating intertwined effects in e-learning programs: A novel hybrid MCDM model based on factor analysis and DEMATEL method[J]. Expert System with Applications, (32), pp. 1028-1044, 2007.

[17] Meng Fansheng, Li Meiying, Research on influence factors of carbon dioxide emissions in China based on the method of combination weights [J]. Operations Research and Management Science, 23(1), pp. 157-165, 2014.

[18] UN DESA, Indicators of sustainable development: guidelines and methodologies (third edition) [M]. United Nations, New York, 10, 2007.

[19] OECD, Towards green growth: Monitoring Progress OECD Indicator [R]. 2011.

[20] The State Council. The state council planned to control the number of population within 1.39 billion during the period of 12th Five Year [EB/OL]. http:// news.163.com/12/0411/02/7UPCEQ9V00014AED.html, April 11, 2012/July 5, 2014. 